\title{
Gender Exclusion in Textbooks: A Comparative Study of Female Representation in Provincial ELT Textbooks of Pakistan
}

\author{
Sajid Waqar ${ }^{1} \&$ Mamuna Ghani ${ }^{2}$ \\ ${ }^{1}$ Department of English, The Islamia University of Bahawalpur, Pakistan \\ ${ }^{2}$ Dean Faculty of Arts, The Islamia University of Bahawalpur, Pakistan \\ Correspondence: Sajid Waqar, The Islamia University of Bahawalpur, Pakistan. E-mail: \\ sajidwaqar20@yahoo.com
}

Received: June 13, 2019 Accepted: July 19, 2019 Online Published: September 6, 2019

doi:10.5539/ijel.v9n5p377 URL: https://doi.org/10.5539/ijel.v9n5p377

\begin{abstract}
The focus of this study was female gender representation in secondary level ELT textbooks published by four different textbook boards of Pakistan, namely Baluchistan Textbook Board, Sindh Textbook Board, Khyber Pakhtunkhwah Textbook Board and Punjab Textbook Board. It targeted a comprehensive comparison between the female gender images as represented in four sets of textbooks and gender conceptions of their respective female readers. To achieve the objectives, the study was divided into two parts: In part 1, the textbooks by four state-run textbook boards were analyzed and in part 2, their respective female readers' gender conceptions were collected and analyzed. The study employed multi-dimensional analytical tools like manifest, latent analysis and Fairclough (2001) CDA model for interpretation and explanation of textbook discourse. The study revealed a low representation share of female gender in four sets of textbooks. It brought out that female readership had stereotype conceptions regarding the attributes, professions and activities as appropriate for the female gender. It was also found that Sindh and Punjab Textbook Boards had improved female gender representation than other provincial textbook boards. The quantitative findings of part 2 proposed that textbooks could play a vital part in modeling gender conceptions of readership as Sindh and Punjab Textbook Boards' female readership showed better gender conceptions. The study recommended a gender-based test of the textbooks at national level prior to publication to ensure gender equality as directed in National Curriculum.
\end{abstract}

Keywords: textbook evaluation, English curriculum, ELT syllabus, female gender representation, critical discourse analysis (CDA), readership conceptions

\section{Introduction}

Curriculum provides basic guidelines for the teaching and learning course of an academic program. It has various stages of planning, execution and evaluation. The complete system of education in fact revolves around curriculum, either directly or indirectly. The significance of an appropriate curriculum rises many times if it is being designed for the language learning course for 2 L learners (Nunan, 1988; Rabbini, 2002; Richards, 2001, quoted in Mahmood, Choudhary, \&Shakir, 2014).

Pakistan is a country with a federal structure of government. Its central government works at the capital city of Islamabad. The federating units are the four provinces, namely Baluchistan, Sindh, Khyber Pakhtunkhwa (KPK) and Punjab. In addition, it has disputed territories of Azad Jammu \& Kashmir (AJK) and Gilgit Baltistan (GB). The education department of the country is run by federal government and education ministries of respective provinces. As per the latest constitutional amendment education is a provincial subject. National language of the country is Urdu whereas; English enjoys the status of second language (2L). Moreover, there is a variety of regional languages spoken in various regions of the country. The national curriculum of Pakistan has gone through many transformations due to various political and other reasons in the past. At present National Curriculum 2006 has been implemented in state-run schools and colleges. The provincial education ministries make their respective syllabus in accordance with the guidelines of National Curriculum 2006. All the provinces have their own textbook boards. However, AJK, GB and the schools under federal education board follow the PTB syllabus. Accordingly, these areas have been grouped with Punjab province for simplicity of data compilation of quantitative part of this study. National Curriculum for English language 2006 (Grades I - XII) provides competencies, standards, benchmarks and student learning outcomes. Various competencies described 
in the curriculum are; reading skills, writing skills, oral communication skills and appropriate ethical and social development. The competency of ethical and social development contains gender equality as one of its components. The provincial textbook boards of Pakistan develop their respective ELT textbooks while conforming to the National Curriculum for English language 2006. Many studies conducted on ELT textbooks in recent past have revealed the prevalence of gender discrimination as reflected in literature review section. The female gender is either excluded or represented in subsidiary roles in ELT textbooks of various countries. So, this study presupposes the presence of gender biases in Pakistani ELT textbooks. The studies conducted to record the gender conceptions of the readership also revealed that the conceptions of students were mostly found in alignment with the gender representation reflected in their textbooks. Mirza (2004) recommended that all the stake holders should be taken on board and evidence-based input, on gender disparities in the curriculum and textbooks, should be provided. The objectives of her paper were to discuss how ELT textbooks of four provinces of Pakistan represented female gender and, to measure and compare the effects of ELT textbooks' contents on gender conceptions of readers.

As per the statistics of National Education Census (2005) the total number of education institutions in Pakistan was 245,682 out of which 164,579 were in public sector and 81,103 were in private sector. The public sector institutions followed the National Curriculum and syllabus of their respective textbook boards. However, the private schools and colleges had the mixture of National Curriculum, Oxford University Press (OUP) and Cambridge syllabus. Anyway, according to rough estimates of NEC 2005 National Curriculum was followed in over $80 \%$ of the total education institutions of Pakistan. Accordingly, it could be assumed that a vast majority of the youth of Pakistan read the syllabus by designed by their provincial textbook boards.

According to Widdowson (2000), ${ }^{\circ} \mathrm{CDA}$ is the uncovering of implicit ideologies embedded in the texts. It explores the underlying ideological bias and therefore the exercise of power in texts'. This study has relied on CDA in deconstructing the embedded themes in textbooks' discourse. The most important aim of CDA is to deconstruct the underlying ideologies of discourse that 'help produce and reproduce unequal power relations in the society (Fairclough \& Wodak, 1997, quoted in Yaqoob, 2011).Yaqoob (2011) explored the cultural and gender conceptions of readership, by using Fairclough's CDA framework, of two different sets of textbooks publishing companies and found out that the conceptions of students were greatly aligned with their respective textbooks' contents. Hameed (2012) was conducted in Pakistan and found out that conceptions of young readership were in line with the contents of its respective textbooks and the students who read the textbooks of OUP, with better gender images, had displayed better gender images than the students who read the textbooks of PTB, with weaker female gender representation.

This study aimed at bringing out and comparing the female representation in ELT textbooks of Baluchistan Textbook Board (BTB), Sindh Textbook Board (STB), Khyber Pakhtunkhwah Textbook Board (KTB) and Punjab Textbook Board (PTB) and recording of gender conceptions of their respective female readership. Fairclough (2001) argues that language should be analyzed as a social practice through the lens of discourse in both speaking and writing. The study has investigated the female representation in ELT textbooks of four provincial textbook boards of Pakistan by relying on manifest and latent content analyses and Fairclough (2001) framework of Critical Discourse Analysis (CDA) in bringing out gender related embedded themes in textbooks' discourse of Pakistan. The research also recorded and quantified the gender conceptions of female readership. Thus, the study endeavored to make the findings valid and reliable through triangulation in data collection and analyses.

\subsection{Significance of the Study}

This study is the first attempt for exploration and comparison of female gender representation in ELT textbooks of four provincial textbook boards, working under a single national curriculum. The research paper has targeted the female gender exclusion in textbooks, the nature of female representation and comparison, in four sets of textbooks. The themes have been decoded by employing CDA framework provided by Fairclough (2001) which suits in-depth analysis according to socio cultural context. The qualitative findings of the study concerning female representation have also been supplemented by quantitative data analysis. The study is significant in another way as the researchers have validated the findings by obtaining gender conceptions of female readership through questionnaire-based survey. Thus, triangulation has been achieved in methods of data collection, data analysis and research design. The recommendations based on the study findings may be helpful for textbook developers in balancing the nature of themes related to female gender in ELT textbooks of four different multicultural provinces while conforming to a single national curriculum. Thus, the stake holders can produce egalitarian texts according to socio cultural environment of different provinces of Pakistan. 


\subsection{Research Questions}

For the purpose of performing the present study the following research questions were framed:

1) How female gender is represented in textbooks of Pakistan's four provinces?

2) How female representation in four sets of textbooks differs from each other?

3) What are the effects of textbooks' contents on gender conceptions of female readers?

\section{Literature Review}

Textbooks are considered as a manipulative instrument for power relations in forming perspectives of learners. Several researchers tried to analyze the representation of gender in ELT textbooks at all levels of education and they have focused on visual and textual representation of female and male characters. Moreover, most of the ELT textbook investigations brought out that gender was always represented in a biased way e.g., Esmaili (2011), Nazeri (2010), Johansson and Malmsj (2009) and Farooq (1999).

Mirza (2004) found that the guidelines for the textbook developers spelled out by the Curriculum Wing contained no guidelines to address the concept of gender equality or equity. The percentage of female authors, reviewers and editors in various provinces of Pakistan was around 25 to $30 \%$. Female gender was $23.1 \%$ of the total characters, $25.7 \%$ in pictures and $20.9 \%$ in school textbooks. The representation of female characters by professions was more visible in KPK and Sindh provinces where females had been given a better share, $31.9 \%$ and $28.1 \%$, compared with that given in Punjab and Baluchistan i.e., 25.1\% and 23.8\% at Primary School level. The attributes such as strong, aggressive, faithful, outstanding, forgiving wise, brave, kind, generous, able, honest and truthful were generally used for males. Females had been represented as modest, dear, helpless, noble, tolerant, expert, domestic worker, blunt, ill-mannered, stubborn, caring, pious and beautiful."

Stockdale (2006) examined only a very few of the possible areas of investigation available to determine if the representation of men and women was balanced. Aly (2007) reported that "Any distinction, exclusion, limitation or preference which, being based on race, color, sex, language, religion, political or other opinion, national or social origin, economic condition or birth, as the purpose or effect of nullifying or impairing equality of treatment in education is tantamount to discrimination."

Yaqoob (2011) used Fairclough (2003) model of CDA and found out that secondary level ELT textbooks published by Punjab Textbook Board (PTB) and Oxford University Press (OUP), being taught in state-run and elite schools of Pakistan respectively, were full of gender biases. The female gender had been marginalized and language of textbooks was sexist. However, female gender representation of OUP textbooks was much improved than PTB textbooks. The quantitative findings of gender conceptions were found aligned with the textbooks' contents of young readership. Like the textbook contents, the gender conceptions of OUP readership were found much better than those of PTB readership.

Van Dijk (1998) writes that 'Critical discourse analysis (CDA) is a type of discourse analytical approach that primarily studies the way social power abuse, dominance, and inequality are enacted, reproduced, and resisted by text and talk in the social and political context'. Taki and Shahbazi (2012) aimed at finding out the differences between female and male characters in terms of discourse features in the conversations of Top Notch series. For that purpose, four elements of gender characters, titles, activities as well as the issue of firstness were investigated in the conversations of the textbook series. The study used Fairclough's (2001) three-dimensional model to extract the embedded themes in textbooks. The findings showed that both genders were represented somewhat differently at least in the conversations. As far the titles, activities and firstness were concerned, it was the females that were represented with inequality. The study brought out the presence of sexism in the dialogues of the series thus supporting the findings of previous studies in that area such as Farooq (1999), Sano et al. (2001), Stockdale (2006), Paivandi (2008), Johanson (2009) and Esmaili (2011). Secondly, the research tried to investigate whether there were any variances between female and male characters pictorially in the series. It was revealed that the series did not have a neutral perspective toward gender in pictorial representation. The findings of the paper also showed that gender representation in the series was reflective of the ideology by which both females and males were signified in those textbooks; the issue denoted what had been termed by Skeleton's (1976) as the "hidden curriculum" enforced on students. Fairclough (2003) said "capitalism economy is an ideology that aims at developing the economic system in which private ownerships, private productions and private benefits could be celebrated. Capitalism teaches the values and norms related to market as supply, demand, price, distribution, investment'. Accordingly, the series as an international distributer of ELT textbooks pursued the ideology of the late twentieth century, recognized as capitalist economy. It indicated that the series intentionally presented both genders in such a manner by which stereotypical norms were ingrained into 
readership's minds.

Shah (2012) found that Pakistan's ELT textbooks of secondary level were not aligned with the National curriculum with regard to inclusion of gender related issues; gender inclusion was virtually invisible, representational ratio of female and male characters was disproportionate and orthodox social roles were assigned to female characters. However, during the interviews the ELT teachers were of the view that gender inclusion was fairly balanced in favour of female gender.

Bartona and Sakwab (2012) concluded that "Simply put, Omission is "when females do not appear as often as males in the text as well as the illustration' (Porecca, 1984, p. 706). A quantitative analysis of gender visibility was carried out by counting the number of females and males present within the text. Females comprised $35.7 \%$ of the appearances while males were $64.3 \%$.A similar imbalance was reported by other researchers (Ansary \& Babaii, 2003; Gupta \& Yin, 1990). As per the Uganda Bureau of Statistics (2011), Uganda's official statistics provided, 'more than half of Uganda's population (51 per cent) was females.' But the ELT textbooks did not have gender balance. The exclusion of women from ELT textbooks had been brought out in other research studies (Bayyurt \& Litosseliti, 2006; Coles, 1977; Davoodi, 1999, Bartona \& Sakwab, 2012). Ansary and Babaii (2003) discovered that there were more male-oriented stories in the Irani textbooks than female oriented ones. $75 \%$ of the gender-specific stories in the study were about males and remaining $25 \%$ represented female gender.

Hameed (2012) carried out comparative analyses of the nature of gender images and gender representation in Punjab Textbook Board (PTB) textbooks and Oxford University Press (OUP) textbooks as the textbooks of both the publishing companies were being taught in a good majority of schools in Pakistan. The findings of the study revealed that gender discrimination was against the female gender with a ratio of 3:1 in linguistic and non-linguistic aspects of the text. The pictorial and textual representation of both genders was clearly in favour of male gender not only, in quantitative aspects but also in qualitative parts. The gender stereotype representation was visible in detailed pictorial analysis as the outdoor and active jobs were attributed to males and passive and domestic activities were associated with female gender. The generic constructions and firstness were also heavily in favour of male gender. The study findings conformed to the results of previous researches in the field like that carried out by Lee and Collins (2004). The gender conceptions of readership of two sets of textbooks were also aligned with their respective textbooks' contents. So, it could be assumed that the textbooks had a direct effect on gender conceptions of the young readership.

Jabeen, Chaudhary and Omar (2014) brought out that in English textbooks majority of the male characters were not involved in any type of activity. Only $27.7 \%$ females in English books were portrayed in outdoor activities. In the text, girls were mostly represented as daughters and the women as mothers, indicating that females had no personality of their own and their identity as a girl was derived from their relationship with a male father and as a woman from their reproductive roles. The text limited the role of woman to that of mother and confined her to the four walls of house; cooking food, carrying water and caring of the children. Girls were best prepared for the roles by learning feminine skills through training with them. Thus, there was no reason for girls to be highly educated, in most of the cases girls were represented in primary schools studies except one or two exceptions. Females were supposed to take permission from their male partners to go outside or to take a decision on financial and household matters. A female's social class was generally determined by her father or husband's occupational status.

Jannati (2015) brought out that most of the female-related adjectives were about the physical appearance and personality of females such as sincere, beautiful, slim, young, emotional, shy, and so on. The attributes like confident, strong and manager of outdoor activities had been associated with male gender in images contained in ELT textbooks.

Majid and Fateme (2015) investigated the representation of gender in an international ELT series, American Headway Student Textbooks by using Fairclough's (2001) three-dimensional framework. The focused variables for gender analysis were social roles, characters, semantic roles, lesson titles, pictorial representation, generic constructions, activities and order of appearance. The study found that female gender was discriminated overtly and covertly. According to the researchers, the study was suggestive of imparting capitalism economy as an ideology.

Samadikhah and Shahrokhi (2015) analyzed and compared the gender representation in Top Notch and Summit series in terms of major aspects of gender by using Fairclough's $(1989,2001)$ models to identify the ideology behind these textbooks. The findings of study indicated that, in most cases, gender representation was more balanced in Top Notch series than in Summit series.

Beiki and Gharaguzlu (2017) aimed at finding out the relations that existed in the discussions of American 
English Files series and to identify the unequal positions distributed between females and males. Consequently, it was discovered that both genders nearly played equal relations and positions. Each gender almost had the occurrence of half of the relations which was suggestive of roughly equal positions of both genders in the relation dimension in American English File series. Regarding gender, the occurrence of positions that each gender had in equal relations was fairly distributed. Each gender almost had the occurrence of half of relations that was suggestive of almost equal positions of both genders in the relative dimension in the American English Files series. With regards to gender, the occurrence of positions which each gender had in equal relations was evenly distributed. Each gender almost had the occurrence of $50 \%$ of relations that was suggestive of around equal positions of genders in the relation dimension in the American English File series.

Demira and Yavuzb (2017) revealed that throughout the 'Yes You Can' course book series, males and females were represented in a strong balance in terms of visibility in the graphics, distribution of domestic roles, household and out-of-home responsibilities, assignment of activities and sports, participation in conversations and text writings, primness in dialogue initiation and text mention, and gender emphasis in writings. With regard to the professions assigned to males and females, there were both positive and negative relations in the course book series. Females were assigned meaningfully more unconventional and fewer conventional careers than males. Therefore, with respect to the quality of professions assigned, 'Yes You Can' was viewed as an exemplary unconventional course book series. Generally, the course book series proved to contain a very ostentatiously distributed, gender-inclusive language and illustrations.

Sulaimani (2017) explored gender representation in English 'Unlimited Special Edition/ level1' textbook used in a 'Kingdom of Saudi Arabia' University. The research used quantitative approach in which descriptive statistical analyses were carried out to investigate male and female frequencies. The investigation of gender representation in the EFL textbook brought out that the material under- represented the females. The number of male characters was clearly more than female characters. Around half of the conversations in the 'course book' were male to male. While men and women were also represented in one of the conversations yet, the total number of male-female conversations was found to be very poor as compared to single gender conversations.

\section{Research Methodology}

This study is exploratory and qualitative in nature and approach. However, quantitative data have also been explored to make the findings more valid and reliable.

\subsection{Research Site}

For the quest of present research, all the provinces of Pakistan i.e., Baluchistan, Sindh, Khyber Pakhtunkhwah (KPK), Azad Jammu \& Kashmir (AJK) and Gilgit Baltistan (GB) areas were selected as site of the study.

\subsection{Study Population}

The population of the present study was all the textbooks of Baluchistan Textbook Board (BTB), Sindh Textbook Board (STB), Khyber Pakhtunkhwah Textbook Board (KTB), Punjab Textbook Board (PTB) and their respective female readership.

\subsection{Sampling}

Sample of the present study was English textbooks of grade IX and X of all the provinces and 1560 female students of government schools of all the provinces. The purpose of this research was to find out the existing female gender representation in the textbooks. So, the reasons to select textbooks of secondary level were; the prevalence of lessons written by local writers of Pakistan, importance of textbooks in the inculcation of gender images in the minds of young readers and optimum comprehension level and age of readership for understanding of questionnaire items written in English language.

Table1. Districts where survey was carried out

\begin{tabular}{llll}
\hline Punjab, AJK and GB & KPK & Baluchistan & Sindh \\
\hline Lahore & Peshawar & Quetta & Karachi \\
Mandi Bahaudin & Abbottabad & Dera Bugti & Hyderabad \\
Bhakhar & Mansehra & Sui, & Sukkar \\
Lodhran & Charsada & Zhob & Pano Aqil \\
Vehari & Karak & Qila Saifullah & Gotki \\
Multan & Hangu & & \\
Skardu & Chitral & & \\
Muzaffarabad & & & \\
Kotli & & & \\
\hline
\end{tabular}




\subsection{The Unit of Analysis}

The unit of the analysis in the present study was the representative data pertaining to female gender representation, extracted from ELT textbooks of all the provinces, titles of lessons, images representing the female gender and female characters, writers and editors of ELT textbooks.

\subsection{Framework of Analysis}

The traditional analytical categories like generic constructions and firstness have not been included in the study. Both manifest and latent content analyses of the content of secondary level ELT textbooks of all the provinces were carried out. In manifest content analysis those features were analyzed which were materially present in the textbook contents and discourses and in latent content analysis, the analysis was extended to the interpretive reading and $\mathrm{CDA}$ of the embedded underlying themes in the representative data.

'Obura: Changing Images' is an elaborate and comprehensive analytical framework. It is a study of Arab, Chinese, Norwegian, and Ukrainian textbooks sponsored by UNESCO. Anna Obura employed her framework for the analysis of twenty-four Kenyan textbooks of natural science, languages, and social sciences used by Primary school in 1985 (cited in Leach, 2000, adopted from Mirza, 2004). The guidelines for the analysis of social roles were taken from Mirza (2004), Collins and Lee (2004), Yaqoob (2011) and Hameed (2012). However, the contents of own study material guided the researchers in developing the analytical categories and framework of analyses. The embedded themes in the representative text, extracted from ELT textbooks, were deconstructed and analyzed by using Fairclough (2001) model of critical discourse analysis (CDA). According to Fairclough, there are three stages of critical discourse analysis.

- Description; It encompasses the linguistic properties of the text under study.

- Interpretation; It involves the discursive practice of production and interpretation of text.

- Explanation; It describes the relationship between production and interpretation processes.

Fairclough (1989) makes distinction between text and discourse, in which he argues that text is a form of product, while discourse is the process - a social interaction process - where text is a part of it. Furthermore, Fairclough (1989) proposes that language is "a socially conditioned process", in which "process" refers to the production of text and the process of interpreting the text and this process itself is related to the practices of the society.

Two terminologies used in the analytical framework are manifest and latent content analysis. The operational definitions of both are:

- Manifest content analysis means analysis of identifiable data on a general observation for quantification.

- Latent content analysis means decoding of embedded and underlying themes.

Table 2. Framework for analysis

\begin{tabular}{l}
\hline The Textbooks \\
Manifest Content Analysis \\
Latent Content Analysis \\
Pictorial Analysis \\
\\
\hline Representative Text \\
Critical Discourse Analysis (CDA) \\
Embedded Themes \\
\hline Readership Conceptions
\end{tabular}

\subsection{Categories for Analysis}

In this study the content of the ELT textbooks of grade IX and X of BTB, STB, KTB and PTB pertaining to female representations were studied. The important categories were as following:

- Female role models 
- Female visibility in titles of units

- Female related lessons

- Female characters

- Female authors/editors

- Personality attributes of female characters

- Pictorial representation of female gender

- CDA of female centered representative text

- Gender conceptions of female readership

\subsection{Limitations of the Study}

As the sample of the research participants was convenient sampling instead of random sampling, the researchers do not claim generalizability of the findings. However, this research is unique as it has compared four sets of ELT syllabus which were under the domain of a single curriculum. So, it has touched the aspects which could be researched in detail at national level in Pakistan. The gender conceptions of students were obtained through closed- ended survey-based questionnaire with five-point Likert's attitudinal scales. The respondents might not be very meticulous regarding their responses resulting into invalid and unreliable findings. The input of various stakeholders of curriculum and syllabus designers could not be obtained through in-depth interviews due to lack of resources and accessibility.

\subsection{Delimitations}

Present study has limited focus as it analyzed ELT textbook syllabus being followed in state-run education institutions of Pakistan's provinces. The Oxford University Press (OUP) and other syllabus have not been touched by the researchers. The contents of only ELT textbooks have been analyzed and remaining subjects taught in government schools have not be included in the study. Similarly, only secondary level ELT textbooks have been studied while omitting primary and elementary level ELT textbooks.

\section{Findings}

\subsection{Female Role Models}

One of the suggested themes in English Language Curriculum 2006 for provincial ELT textbooks is of the 'role models'. Mostly, the role models were visible in the form of religious and male personalities in ELT textbooks of all the provinces. However, some provincial textbook boards had included females also as role models. Table 3 shows the comparison of this aspect.

Table 3. Female role models

\begin{tabular}{llll}
\hline BTB & STB & KTB & PTB \\
\hline Nil & Hellen Keller & Begum Rana Liaqat Ali Khan & Hazrat Asma (RA) \\
\hline
\end{tabular}

\subsection{Female Visibility in Themes of Units}

There were certain units in the textbooks that centered on female characters. However, the titles of such lessons did not explicitly show female naming forms. This section contains the number of such units in ELT textbooks of all the provinces. Table 4 below shows the details.

Table 4. Units with female themes

\begin{tabular}{llll}
\hline Publishing board & Total No of units & Units with female themes & \%age of female centered units \\
\hline BTB & 34 & 1 & 3 \\
STB & 47 & 5 & 11 \\
KPK & 28 & 3 & 7 \\
PTB & 25 & 3 & 12 \\
\hline
\end{tabular}

\subsection{Female Characters}

The authors of most of the publishing boards had included a small number of female characters in majority of the ELT textbooks. However, female characters were in a good number in Sindh Textbook Board's ELT textbooks. 
Table 5 shows the exact comparison.

Table 5. Number of female characters

\begin{tabular}{ll}
\hline Publishing board & No of female characters \\
\hline BTB & 2 \\
STB & 15 \\
KTB & 3 \\
PTB & 3 \\
\hline
\end{tabular}

\subsection{Female Authors/Editors}

Female authors of lessons and editors of textbooks of respective provinces were grouped together. PTB was having a good percentage of female authors whereas; BTB also had a satisfactory percentage of females. The remaining two provinces have a lesser number and percentage of female authors/editors.

Table 6. Percentage of female authors/editors

\begin{tabular}{llll}
\hline Publishing board & Total No of authors & Number & \%age within the provinces \\
\hline BTB & 24 & 7 & 42 \\
STB & 14 & 2 & 16 \\
KTB & 14 & 3 & 24 \\
PTB & 6 & 4 & 66 \\
\hline
\end{tabular}

\subsection{Female Personality Attributes}

It was observed that very few personality attributes had been used for females in all the textbook boards' ELT textbooks. However, the quality of the attributes was very much satisfactory. The stereotype adjectives were less in number in textbooks of all the provinces.

Table 7. Female personality attributes

\begin{tabular}{ll}
\hline Publishing board & Attributes \\
\hline BTB & Devoted, punctual, active, \\
STB & Brave (2), courageous, wonderful, fair, beautiful, divine, selfless, spirited, upright \\
KTB & Pretty, organizer, crusader, helping, caring, reformer, pioneer, hardworking, Female rights activist \\
PTB & Courageous, generous, wise, determined, \\
\hline
\end{tabular}

\subsection{Female Professional Representation}

Females were either depicted as nurses or had been motivated to join the profession of nursing due to its suitability for females and deficiency of female nurses in Pakistan. They were not represented as teachers, physicians and engineers etc.

Table 8. Female professions

\begin{tabular}{llll}
\hline BTB & STB & KPK & PTB \\
\hline Nursing & Nursing & Nursing & Nursing \\
\hline
\end{tabular}

\subsection{Representation of Females in Social Roles}

Females were represented in stereo type family and social roles in the ELT textbooks of all the four provincial textbook boards. Table 9 describes the exact roles of female gender depicted in the textbooks.

Table 9.Female social roles

\begin{tabular}{llll}
\hline BTB & STB & KPK & PTB \\
\hline Motherly, sisterly, & House maker & Motherly & House maker \\
\hline
\end{tabular}




\subsection{Pictorial Representation of Female Gender}

The manifest analysis of ELT textbooks revealed that the female gender had very nominal pictorial representation in the textbooks' contents, cover pages and exercises. Table 10 below, reflects the quantitative comparison of female pictures in the textbooks of four provincial textbook boards. BTB textbooks contained slightly better female pictorial representation than the remaining provinces.

Table 10. Female pictorial representation

\begin{tabular}{lllll}
\hline Publishing board & Female only & More females & Female \&male Mixed & Total \\
\hline BTB & 2 & 1 & 5 & 8 \\
STB & 6 & Nil & Nil & 6 \\
KTB & 2 & 1 & Nil & 3 \\
PTB & 2 & 1 & 3 & 6 \\
\hline
\end{tabular}

\subsection{CDA and Comparison of Feminine Themes in Provincial Secondary English Textbooks}

This section is about the nature of female related themes embedded in the discourse of all the four provincial textbook boards' secondary level English textbooks. As already mentioned, the critical discourse analysis (CDA) model provided by Fairclough (2001), has been used to bring out the embedded themes and worldview in the discourse of ELT textbooks. The comparison with male gender, based on attributes was not done in the study. Since, qualitative comparison was under consideration therefore, the in-depth analysis focused on socio cultural context of the representative text.

\subsubsection{Baluchistan Textbook Board (BTB)}

Mills (1995) says that 'we have to consider our assumptions about texts and the relation they have with context and readers, since frequently it is here that assumptions about gender are most at work'. The women of Baluchistan have been described as object of beauty while wearing ornamental dresses and jewelry. Their social role has been depicted being restricted to four walls of their houses. At another instance the profession of nursing has been attributed to female gender because of their sensitive and caring nature. The active role of women in social or professional field has not been represented at all in BTB discourse. Moreover, no female role model was found visible in BTB textbooks' discourse.

Table 11. BTB-feminine themes in ELT textbooks

\begin{tabular}{lll}
\hline Unit titles & Nature of themes & Attributes, Key words \\
\hline 'The Customs of Various Regions of & Object of beauty, Professional stereotype & $\begin{array}{l}\text { Jewelry, attractive, attends to household work, beads } \\
\text { \& mirrors, sensitive, caring and tolerant. }\end{array}$ \\
\hline
\end{tabular}

\subsubsection{Sindh Textbook Board (STB)}

Women have been represented in social stereotype in STB books. The unit on shopping is an interesting account of the domestic routine of a middle-class family. The mother has been described; working in kitchen and concerned about the replenishment of groceries, while her husband was away on a routine business tour. She planned to go for shopping out of compulsion. She has been represented while accompanied by her son and daughter because it does not seem a normal practice for a middle-class woman in Pakistan to visit the market without company of a male member of her family. So, the discourse of the lesson is the typical representation of a woman in stereo type social role. The poem, written by a western poet about motherly role and responsibilities, also represents women in social stereotype role. The women have been portrayed as delicate and fragile object of nature in the poem.

Table 12. STB-feminine themes in ELT textbooks

\begin{tabular}{lll}
\hline Unit titles & Nature of themes & Attributes/Key words \\
\hline "Shopping", "The Hand that Rocks the Cradle is & $\begin{array}{l}\text { Social stereotype, motherly role, weak } \\
\text { Gender }\end{array}$ & $\begin{array}{l}\text { Kitchen, father always does the shopping, } \\
\text { Angels, Rainbow, }\end{array}$ \\
'The Customs of Various Regions of Pakistan' & & \\
\hline
\end{tabular}




\subsubsection{Khyber Pakhtunkhwah Textbook Board (KTB)}

The next province whose feminist discourse is going to be discussed is KPK. Majority of population of this province is traditional and conservative Pathans. However, this province has a high female literacy rate (NEC, 2005).The first unit that depicts the women of KPK is a travelogue written by a western female writer. The writer is fascinated by the natural beauty and sights of mountainous terrain of Swat valley. The women folk of the area has been identified and represented with the beauty of the natural sights. Moreover, the women folk have been portrayed while carrying load on their heads. It is a common practice for women folk in many rural areas of Pakistan to work in the fields and attend to the livestock. The western traveler has objectively depicted and described this cultural practice. As far textbook themes are concerned, the lesson has been included in the textbook as a travelogue. The women depiction seems unconscious on the part of the author. But for the young readership the effect is the same whether the depiction of female social role is consciously or unconsciously represented. The next lesson that represents women is a poem written by an American male poet. The poet is most likely influenced by social role of women in his own western society but the publisher of KTB has included the poem in the secondary level textbook out of stereo type influence and impression of women folk in KPK society. The very title of the poem 'The Old Woman' evokes the feelings of sympathy in the minds of readership. The phrases 'spent radiance' and 'white candle' also assign no productive, active or intellectual role to the women. The next unit in KPK secondary English textbooks that pertains to females is about the life of a famous and influential personality, Begum Rana Liaquat Ali Khan. The lesson has been grouped under the heading of 'Gender Equality'. The National Curriculum 2006 directs the provincial textbook boards to include this important theme in their syllabus. So, the theme of gender equality has been explicitly included in the textbook. The female role model has been described as the 'crusader' of women rights. She has been represented as a social and political worker for the uplift of women in general and Muslim women in particular.

Table 13. KTB-feminine themes in ELT textbooks

\begin{tabular}{lll}
\hline Unit titles & Nature of themes & Attributes/Key words \\
\hline 'Swat Valley', 'The Old Woman', 'Begum & $\begin{array}{l}\text { Source of beauty, social stereotype, source } \\
\text { of sympathy, female social rights, Pakistan } \\
\text { Rana Liaquat Ali Khan' }\end{array}$ & $\begin{array}{l}\text { women had big baskets on their heads, pretty } \\
\text { Movement, Role Model }\end{array}$ \\
\hline
\end{tabular}

\subsubsection{Punjab Textbook Board (PTB)}

The PTB textbook discourse is silent on stereotype social, family roles and attributes of the female gender. The generic constructions are almost negligible and the general pattern of firstness of male gender is not also much explicit in the discourse of PTB textbooks. It seems that there has been a conscious effort to make the contents of English lessons more and more egalitarian. The unit of PTB textbook representing female gender is 'Hazrat Asma (RA)'. She was daughter of Hazrat Abu Bakr (RA), the first caliph of Islam. The respected lady has been represented while intelligently aiding Holy Prophet (PBUH) during his migration from the city of Makah to Medina. She displayed unmatched courage and wisdom during execution of hilarious task of assisting the Holy Prophet (PBUH) and her own father Hazrat Abu Bakr Siddique (RA). Moreover, the lady has been described while performing the charitable tasks for the general uplift of down trodden humanity. She has been termed as generous person by the author. Otherwise, the attributes of generosity, courage and wisdom for females are very sparing used in textbooks and social environments of Pakistan's society.

Table 14. PTB-feminine themes in ELT textbooks

\begin{tabular}{lll}
\hline Unit titles & Nature of theme & Attributes/Key words \\
\hline Hazrat Asma (RA) & Islamic history, Female Role Model & courage, generosity and wisdom, \\
\hline
\end{tabular}

\subsection{Gender Conceptions of Readership}

The female readership conceptions were obtained through close ended questionnaire-based survey. Five-point Likert attitudinal scales were used for the purpose. The questionnaire was administered to 1560 female secondary level students of rural and urban areas of all the provinces of Pakistan. In fact, the relevant questions to gender conceptions were extracted from a larger $\mathrm{PhD}$ study questionnaire. Moreover, the male students' responses were excluded as per the scope of this paper. It is pertinent to mention that going out of home alone, working freely with males and even studying together with males is not very common and socially acceptable for 
females in Pakistan. The female gender has a limited access to outdoor activities in social structure of Pakistan. The researchers endeavored to obtain readership's conceptions through indirect inference. In Pakistan's socio-cultural environments, the females are generally reluctant to express on gender equality. The validity of questionnaire in accordance with socio cultural context of Pakistan and research ethics was approved by the research supervisor and a board of research experts. The number of respondents and detail of their responses is noted below the Table 15 .

Table 15. Gender conceptions of readership

\begin{tabular}{lllll}
\hline Question statement & Province & Responses & \\
\cline { 3 - 4 } & & A $\%$ & DA\% & DK\% \\
\hline Girls should drive car & Baluchistan & 18 & 73 & 9 \\
& Sindh & 55 & 42 & 3 \\
Women should work in all professions with men & KPK & 33 & 59 & 8 \\
& Punjab/AJK/GB & 51 & 43 & 6 \\
& Baluchistan & 20 & 68 & 11 \\
There should be co-education in schools & Sindh & 48 & 44 & 8 \\
& KPK & 21 & 70 & 9 \\
& Punjab/AJK/GB & 40 & 53 & 7 \\
& Baluchistan & 11 & 82 & 7 \\
Females should go to restaurant with friends & Sindh & 45 & 53 & 2 \\
& KPK & 19 & 70 & 11 \\
& Punjab/AJK/GB & 41 & 56 & 3 \\
& Baluchistan & 9 & 76 & 15 \\
& Sindh & 40 & 55 & 5 \\
\end{tabular}

Note. Number of female student respondents: Baluchistan-210, Sindh-305, KPK-230, Punjab/AJK/GB-815, Total-1560.

Key: A = Agree, DA = Disagree, DK= Don't Know, \% = Percentage. All values are reported as percentage for simplicity of comparison.

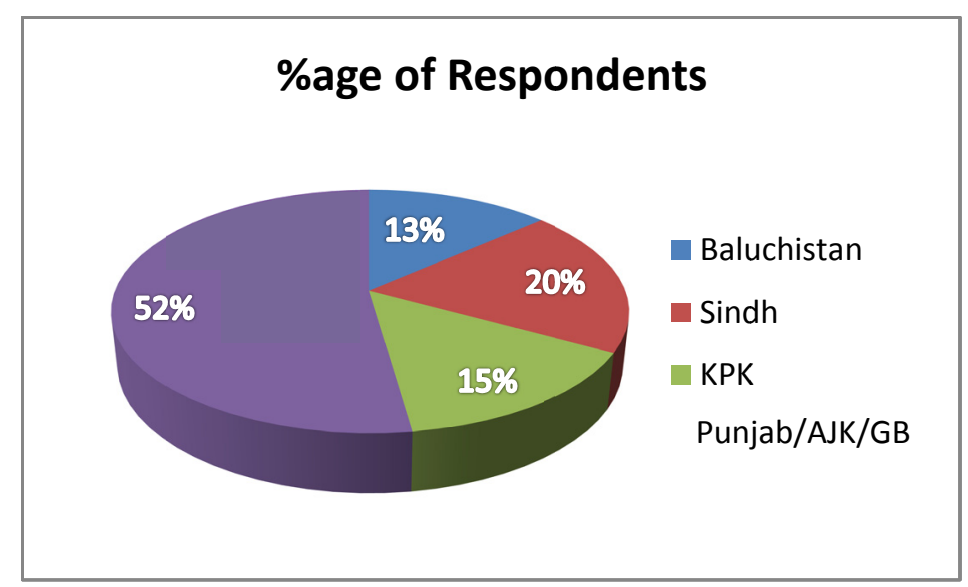

Figure 1. \%age of respondents 


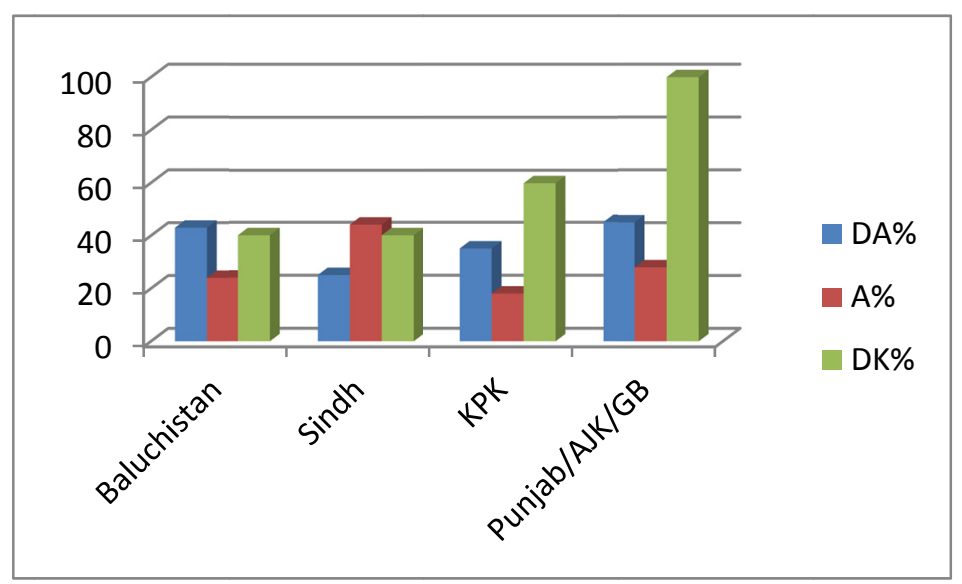

Figure 2. Women should work in all professions with men

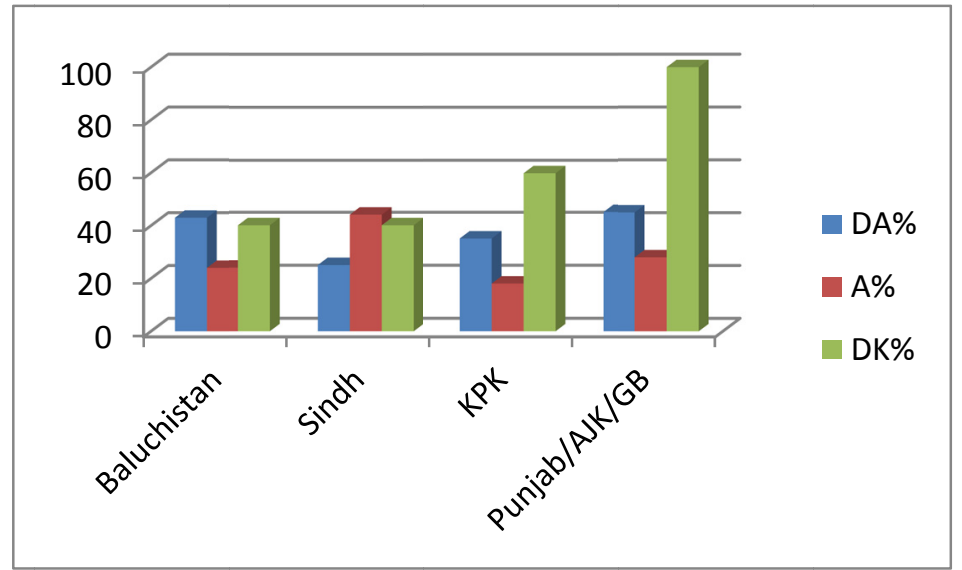

Figure 3. Girls should drive car

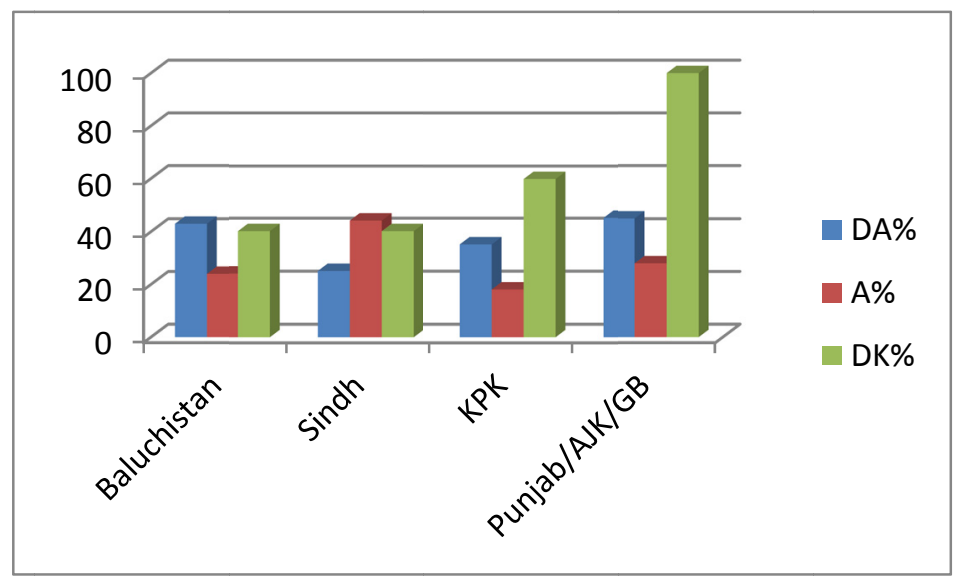

Figure 4. There should be co-education in schools 


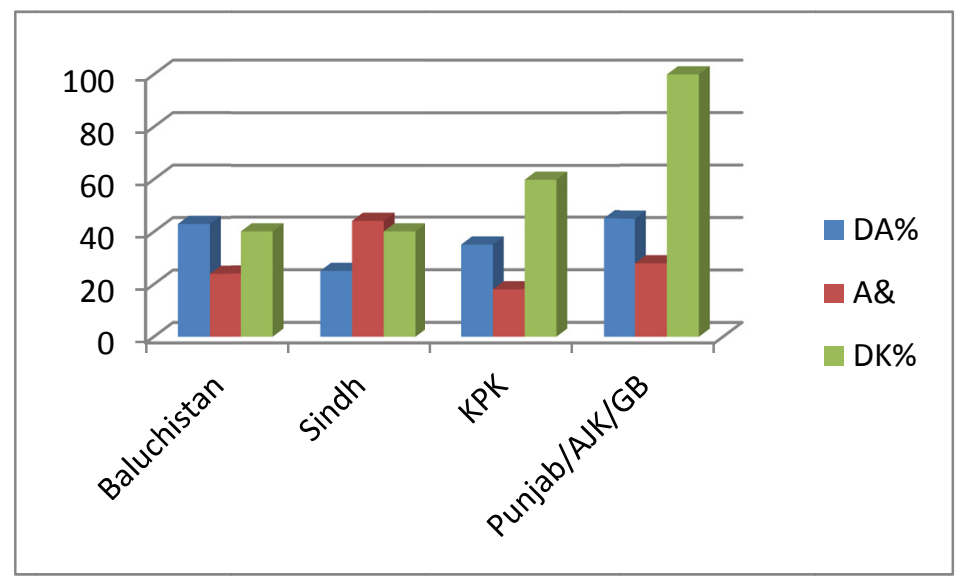

Figure 5. Females should go to restaurant with friends

The number of respondents of different provinces was not kept uniform during survey as the actual population of the provinces is not same. The respondents' number had been kept in ratio with the actual population of the provinces. However, for easy comprehension of comparison, the data in Table 15 and figures have been shown in percentage rather than in number of respondents. The responses of female readers on the questionnaire items suggest that a large number of female students of all the provinces of Pakistan seemed reluctant to take active part in social and professional spheres of life where there were males. Some students were not even ready to express their opinion on certain questions probably due to social reasons. The limited role of females in outdoor activities and professional spheres has also been reflected in qualitative and quantitative data of female gender representation in ELT textbooks. The comparative results of survey suggest that the female readership of STB and PTB has improved gender conceptions than remaining provinces.

\section{Discussion}

The ELT textbooks prescribed for 9th and 10th class Baluchistan Textbook Board, Sindh Textbook Board, Khyber Pakhtunkhwah Textbook Board and Punjab Textbook Board, Lahore, Pakistan were examined in detail. Due to the limited scope of the study only the ELT textbooks were focused while leaving aside the textbooks of other subjects. Likewise, the ELT textbooks of only grade IX and X could be included in the study. The textbooks of private publishing companies are taught in a good number of private schools in Pakistan. However, the study could focus only on the textbooks of state-run schools. The research question 1 was about the manner of female representation. The study has revealed that barring a few instances, the female gender has not been given its due share in ELT textbooks. The 2nd research question was about the comparison of female representation in ELT textbooks of four provincial textbook boards. Despite the fact that the four provincial textbook boards follow the guidelines of National Curriculum for English language Grades I - XII 2006, the female representation in linguistic, non-linguistic and semiotic features was not uniform in both the qualitative and quantitative aspects. The pictorial representation of female gender was very low in the ELT textbooks of all the four provincial textbook boards. The 3rd research question pertained to the effects of textbooks' contents on gender conceptions of female readers. It was very difficult to collect the gender conceptions of female readership through multiple research instruments like interviews and observations. The large number of respondents dictated the reliance on survey method. The data obtained through questionnaire-based survey revealed that the female readership lacked the requisite drive for emancipation. Female students seemed satisfied with the social and gender roles assigned to them in textbook and social discourse of the nation.

It is very pertinent to add that socio cultural and religious environment have deeper effects on the mindset and gender ideas of young readership. So, the effects on readership's conceptions cannot be fully attributed to the textbook contents. The comparison of readership conceptions between provincial textbook boards' readership found that STB and PTB readership had much better conceptions than those of KTB and BTB which was reasonably in consonance with the nature of female representation in textbook contents of their respective textbook boards. The results of this paper are fairly in line with the findings of Mirza (2004), Yaqoob (2011), Hameed (2012), Shah (2012) and Jabeen, Chaudhary and Omar (2014), Ahmad and Shah (2019).

\section{Conclusion}

This study was aimed at examining the nature of female gender images and related discourse depicted in the ELT 
textbooks of Pakistan's four provincial textbook boards i.e., BTB, STB, KTB and PTB. Moreover, one of its objectives was to compare the nature of female gender representation, displayed in four sets of ELT textbooks, published by respective provincial textbook boards; and type of gender views the female readers of the respective textbooks have. The study comprised two parts i.e., textbook analysis and analysis of readership's conceptions. Mixed method research approach was used for collection and analysis of data. Latent and manifest content analyses along with Critical Discourse Analysis (CDA) of representative text selected from ELT textbooks were carried out to deconstruct implicit themes embedded in textbook discourse. The results revealed that female gender representation was much below the desired standards of gender equality. However, on comparative basis the female gender representation in Sindh Textbook Board (STB) and Punjab Textbook Board(PTB) textbooks were much better than those of Khyber Pakhtunkhwah Textbook Board (KTB) and Baluchistan Textbook Board (BTB) textbooks. Likewise, female readership conceptions of PTB and STB were much improved than those of KTB and BTB. This finding is suggestive of effects of textbook themes on readership's mind.

\section{Recommendations}

The fair representation of the feminine gender in ELT textbooks will make the students appreciate the contribution and worth of women as a productive and important component of the society. A deliberate study of all the ELT textbooks taught in Pakistan should be conducted to ensure the optimum inclusion of the female gender. The representation of females in characters, pictures and professional roles needs much improvement. All the provincial textbook boards should carry out the reappraisal of textbooks' content so as to ensure gender equality in the light of National Curriculum 2006.

\section{Acknowledgement}

This research paper titled "Gender Exclusion In Textbooks: A Comparative Study of Female Representation in Provincial ELT Textbooks of Pakistan" has been extracted from the PhD Thesis titled "Ethics and Culture in Textbooks: A Comparative Study of ELT Syllabus of Pakistan's Provinces" which was conducted by Sajid Waqar under the supervision of Prof. Dr. Mamuna Ghani, Dean Faculty of Arts, The Islamia University of Bahawalpur, Pakistan and is being published in partial fulfillment of the requirements for the degree of $\mathrm{PhD}$ in Linguistics at The Islamia University of Bahawalpur, Pakistan.

\section{References}

Aftab, A. (2012). English language textbooks evaluation in Pakistan. Doctoral dissertation, University of Birmingham.

Ahmad, M., \& Shah, S. K. (2019). A Critical Discourse Analysis of Gender Representations in the Content of 5th Grade English Language Textbook. International and Multidisciplinary Journal of Social Sciences, 8(1), 124. https://doi.org/10.17583/rimcis.2019.3989

Ali, S., \&Tahir, M. S. (2009). Reforming education in Pakistan-tracing global links. Journal of Research and Reflections in Education, 3(15), 1.

Aly, J. H. (2007). Education in Pakistan a White Paper revised-document to debate and finalize the National Education Policy. Ministry of Education, Government of Pakistan, Islamabad. Retrieved from www.moe.gov.pk/nepr/White Paper. pdf.

Barton, A., \& Sakwa, L. N. (2012). The representation of gender in English textbooks in Uganda. Pedagogy, Culture \& Society, 20(2), 173-190. https://doi.org/10.1080/14681366.2012.669394

Beiki, M., \& Gharaguzlu, N. (2017). The Analysis of Iranian English School Text Book: A CDA Study Based on Norman Fairclough's 1989 Model. International Journal of Humanities and Cultural Studies, 4(1), 55-67.

Chalak, A., \& Ghasemi, B. (2017). A Critical Discourse Analysis of Four Advanced ELT Textbooks Based on Fairclough's Framework. Research in Applied Linguistics, 8, 60-66.

Dabbagh, A. (2016). Gender representation under critical image analysis: The case of Iranian ELT textbooks. International Journal of English Language \& Translation Studies, 4(4), 39-52.

Demir, Y., \&Yavuz, M. (2017). Do ELT course books still suffer from gender inequalities? A case study from Turkey. Journal of Language and Linguistic Studies, 13(1), 103-122.

Fatima, G., Shah, S. K., \& Sultan, H. (2015). Textbook analysis and evaluation of 7th \& 8th Grade in Pakistani context. International Journal of English Language Teaching, 3(4), 79-97.

Hameed, A. (2012). A GENDER-BASED STUDY OF ENGLISH TEXTBOOKS PRODUCED BY PUNJAB 
TEXTBOOK BOARD AND OXFORD UNIVERSITY PRESS FOR ELEMENTARY LEVEL. Doctoral dissertation, NATIONAL UNIVERSITY OF MODERN LANGUAGES (NUML) ISLAMABAD.

Jamalvandi, B. (2014). ELT textbook evaluation in Iran, new insights. European Online Journal of Natural and Social Sciences, 3(4), 1068.

Jannati, S. (2015). Gender representation in EFL textbooks: A case of ILI pre-intermediate series. Journal of Applied Linguistics and Language Research, 2(3), 211-222.

Mahboudi, H. R., \& Javdani, F. (2012). The teaching of English in Iran: The place of culture. Journal of Languages and Culture, 3(5), 87-95.

Mahmood, M. A., Rasheed, S., Obaid, M., \& Shakir, A. Representation of Class System through English Textbooks in Pakistan.

Mirza, M. (2006). Gender analysis of school curriculum and textbooks UNESCO. Islamabad, Pakistan. Retrieved October, 25, 2010.

Mustapha, A. S. (2013). Gender and Language Education Research: A Review. Journal of Language Teaching \& Research, 4(3). https://doi.org/10.4304/j1tr.4.3.454-463

Naseem, S., Shah, S. K., \&Tabassum, S. (2015). Evaluation of English textbook in Pakistan: A case study of Punjab textbook for 9th class. European Journal of English Language and Literature Studies, 3(3), $24-42$.

Shah, S. F. (2012). Gender Inclusion: A Neglected Aspect of the English Textbooks in Pakistan. International Journal of Social Sciences \& Education, 3(1).

Sulaimani, A. (2017). Gender Representation in EFL Textbooks in Saudi Arabia: A Fair Deal? English Language Teaching, 10(6), 44-52. https://doi.org/10.5539/elt.v10n6p44

Taki, S., \& Shahbazi, A. (2012). Gender Representation in ELT Materials: A Critical Discourse Analysis of Top Notch. Journal of Language, Culture, and Translation, 1(1), 105-118.

Vettorel, P., \& Lopriore, L. (2013). Women's voices in English course-books in Italy: a diachronic survey from the 50 s to the 80 s. Lingue e Linguaggi, 10, 137-168.

Yaqoob, M. T. (2011). Ideology and worldview in textbooks: A study of cultural aspects in ELT in Pakistan. Doctoral dissertation, Bahauddin Zakariya University, Multan.

\section{Appendix}

\section{Table of Acronyms}

\begin{tabular}{ll}
\hline PTB & Punjab Textbook Board \\
STB & Sindh Textbook Board \\
KTB & Khyber Pakhtunkhwa Textbook Board \\
BTB & Baluchistan Textbook Board \\
OUP & Oxford University Press \\
AJK & Azad Jammu \& Kashmir \\
GB & Gilgit Baltistan \\
KPK & Khyber Pakhtunkhwa \\
CDA & Critical Discourse Analysis \\
ELT & English Language Teaching \\
2L & Second Language \\
NEC & National Education Census \\
PBUH & Peace Be Upon Him \\
\hline
\end{tabular}

\section{Copyrights}

Copyright for this article is retained by the author, with first publication rights granted to the journal.

This is an open-access article distributed under the terms and conditions of the Creative Commons Attribution license (http://creativecommons.org/licenses/by/4.0/). 